\title{
Large Scale Analysis of Molecular Dynamics by Parallel Processing
}

\author{
○高橋 昭如（東大工:[院]） 正 知 元基（東大工） \\ Akiyuki Takahashi, University of Tokyo, 7-3-1, Hongo, Bunkyo, Tokyo, 113-8656 \\ Genki Yagawa, ibid.
}

Key Words : Molecular Dynamics, Johnson Potential. Spatial Decomposition. PC cluster

1. 緒言

往来き裂を含む構浩物およびき裂そのものは捙続体少学を基にし た破壊打学ハシメータである応力应大保数やJ積分值を用いて解析 が行われてきた、しかし、これらの破壊力学ハラメー夕はマクロな 梘点からき裂をとらえているためにきれつの谁展の本質的なメカ二 ズムなよ゙を調べるこ上ができなかった。そこで、近年原子（分子） を計算におい陽に取り扱い原子そのもののダイナミクスを計算す る分子動才学法のき㤠問題への適用か試みられている：しかし、分 子動力学法により取り扱うこ上のできる領域は極めて小さいために 構造物のマクロな挙動は有限要素法で解析し、き裂先端付近は分子 動力学法で解析するマルチスケール解析手法も提案されている[1] また近年のコンビュータ、特に超並列計算機や、PC クラスタの准 歩により計算に取り扱うことのできる原子の数は極めて大きくなり つつある|2l

本報では大規模なマルチスケール解析（原子領域で 10 億原子） を目標に MPI(Message Passing Interface)を用いて分子動力学法 の並列化を行い、PC クラスタ上に実装した。PC クラスタ上での並 列分子動力学法の並列性能を評価し、分子動力学法によるき裂問題 解析の例を示寸。

2.1 分子動力学法

\section{2. 計算手法}

本研究では、鉄を解析対象上し、式(1)に示すような綾験的 2 体間 ポテンシャルである Johnson"13ポテンシャル[4]を用いな。

$$
\Phi=C_{0}\left(r-C_{1}\right)^{3}+C_{2} r+C_{3}
$$

また、時間積分には Velocity Verlet楛゙を用いた。本方法は初期条件 として各原子の座標々速度を指定し計算を行う。

\section{2 分子動力学法の並列化}

分子動力学法の並列化は最も一般的に用いられている Spatial

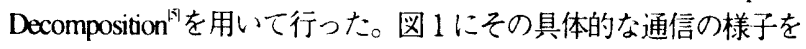
示す。

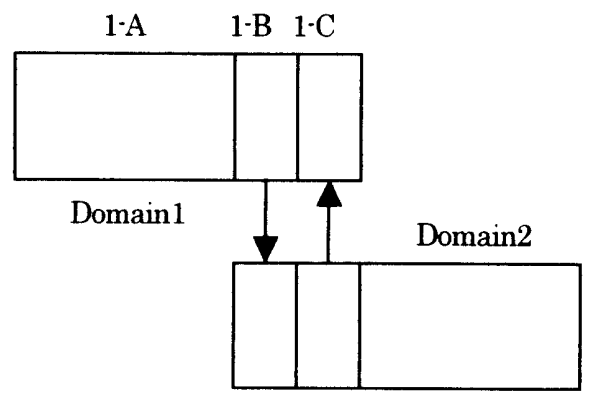

2-C 2-B 2-A

Fig.l Spatial Decomposition Method
領域 1 においい領域 に一は本来領域 2-A の影響も考慮しなければな らないか領域を分割されているために領域1内では完全に原子にか

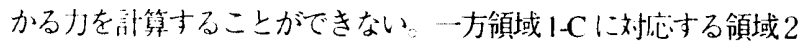
内の領域 2-B は影制範用の原子がすべて領域 2内にあるので原子に かかる力の䔘を完全に行うことができる、そこで、領域2-Bにお いては各原子にかかる力を計算し、座標を更新した後に領域2-Bの 原子の座標を領域に一Cに通信し領域I-Cの原子の座標とする。た 領域 I-B,領域 2-Cについても同様である。

\section{3. 並列性能評価}

並列化した分子動力学法コードをPCクラスタ (VT-Alpha533MHz, 512MB, Fast Ethemet）上に実装し、PC クラスタ上での並列性能につ いて調べた図2に計算に用いたモデルと同等の形状のモデルを示 す。本研究はき裂問題の解析を对象としているので、図2のように 正方形領域の左端部から中央部に向けてき裂がモデル化されている。 また、正方形領域の端部領域の原子には、与えられた応力拡大倸数 によって求められて線形弾性解に従う速度を与える。上下のき裂面 間距離は相互作用力か䡃かないようにJohnson ポテンシャルのカッ トオフ距離以上にした。板圧方向には周期的境界条件を与え平面ひ ずみ状態を仮定する。帮祭に並列性能評価に用いたモデルは原子数 10372665 である。

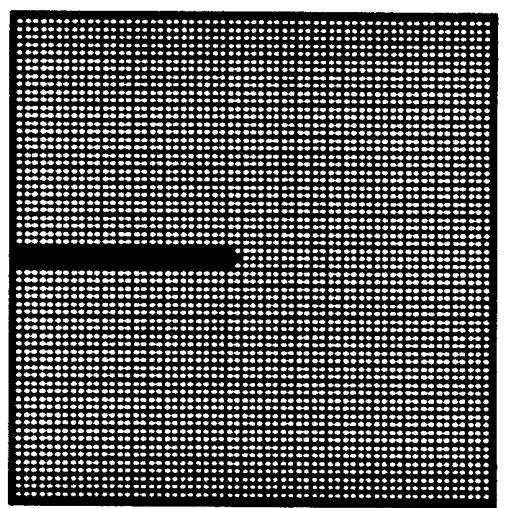

Fig.2 MD Model with a Crack (18180 Atoms)

並列化によるスピードアップの様子を計算する上では式(2)に示 すように計算機 1 台を用いて計算したときに要する計算時間を知る ことが必要であるが、10372665 原子の計算を 1 台の計算機を用いて 行うことは極めて困難である。

$$
\text { Speedup }=\frac{T_{1}}{T_{n}}
$$

ここで、式(2)中の $T_{1} 1$ 台の計算機を用いて計算したときの時間を 
示し、 $\mathrm{T}_{n}$ はn台の計算機を用いて計算した上きの時間を示寸 ここ で、式(2)のTは何台の計算機を用いた場合も一定であるので、ここ では各台数の計算機に上る計算時間の逆数を上り、その公配の様子 から並列性能を推測寸る; 計算時間の逆数を取った上きのグラフを 图3に示吉，般にスヒードアップ曲線ははほほ直線的にニスヒード アップした後に曲線を描きスビードアッフが停滞寸る傾问がある

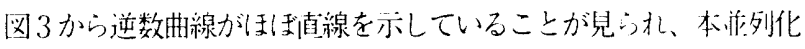
分子動力学法がPC クラスタ上で良好なスピードアッフ在小!てい るこ上がわかる

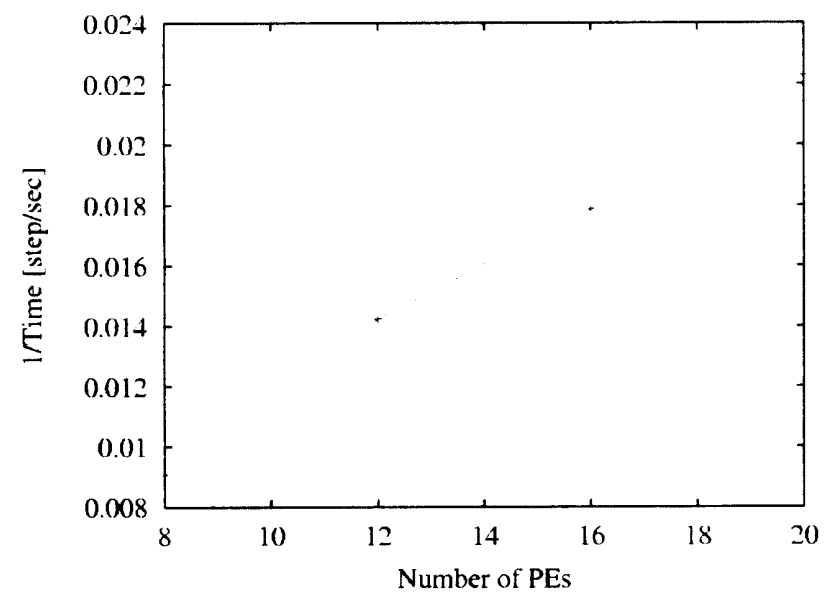

Fig.3 Estimation of parallel performance

\section{4. き裂問題の解析例}

PC クラスタ環境上での並列分子動力学法解析の例上して、き裂 問題の解析を図 2 上同樣の形状を有するモデルを用いて行のた。解 析において与えた諸条件を表1に示吉。

Table.1 Analysis Conditions

\begin{tabular}{|c|c|}
\hline Stress Intensity Factor $\mathrm{K}_{\mathrm{f}}$ & $8.14 \mathrm{MPa} \cdot \mathrm{m}^{12}$ \\
\hline Initital position & b.c.c. \\
\hline Temperature & $300 \mathrm{~K}$ \\
\hline Potential & Johnson potential \\
\hline Temperature Control & Velocity scaling method \\
\hline
\end{tabular}

解析に用いたモデルは原子数が2,050,065 で、モデルの+イズは約 $0.129 \mu \mathrm{m} \times 0.129 \mu \mathrm{m}$ で、厚さ方向は $1.43 \mathrm{~nm}$ である。Spatial decomposition を用いて領域を $4 \times 4$ に分割し 16 台のPC を用いて 解析を行った。正方領域の境界付近の原子には応力拡大係数によっ て求められる線形弾性解の变位を速度境界条件として与えた。図 4 に時刻 $16 \mathrm{ps}$ (図 4 (a)）と時刻 32ps(図4 (b)) の時のき裂准展の様子を 示す。初期き裂の先端の位置は図 4 (a)の左からおよそ4分の 1 の位 置にある。図4 (a)を見ると、き裂は初期のき裂方向にほほまっすぐ 進展しており、また破面は非常に平らになっている様子が見られ、 脆性的に破壊している様子が見られる。図4(b)からは、き裂か図4 (a)の時刻からさらに脆性的に進展し、その後でき裂先端が鈍化し、 き裂が 2 方向に分岐している様子が見られる。また、分岐後の破面 は極めて粗くなっており、ディンプル破面に良く似た様相を示して いる。本モデルは原子によって構成されたモデルであり、極めて微 視的なものであるのでディンプル破壊か圮きたということは難しい が、脆性的に進展していたき裂が、延性的な破壊に遷移したと考え ることができる。

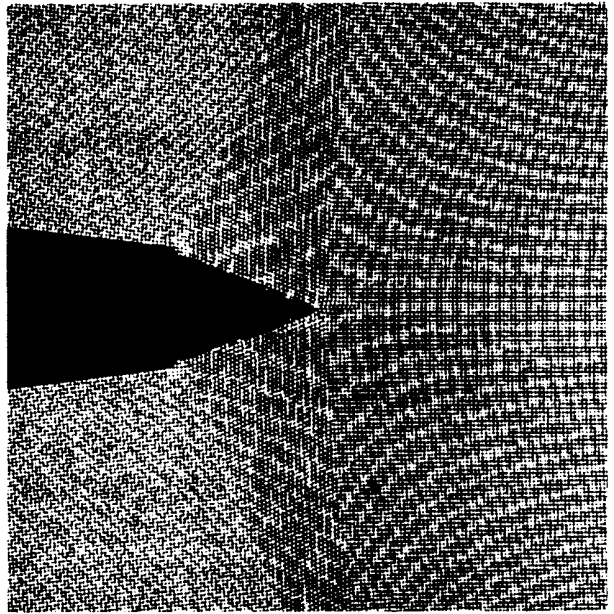

(h) $16 \mathrm{ps}$

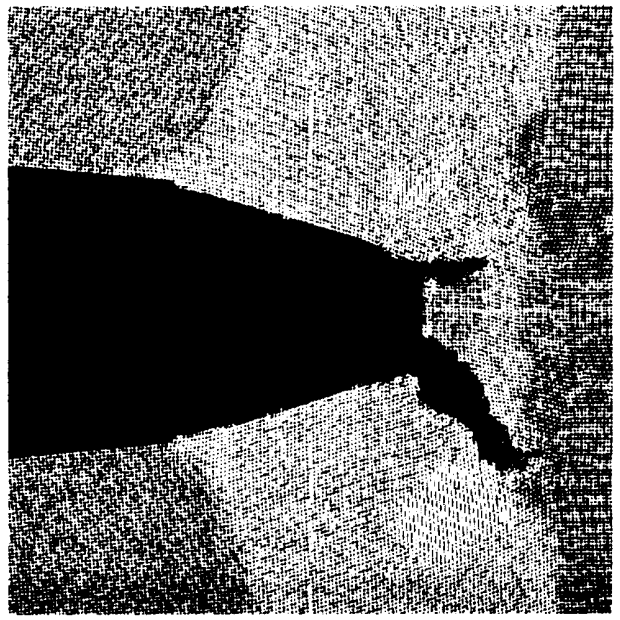

(b) $32 \mathrm{ps}$

Fig.4 Crack propagation

\section{5. 結言}

Spatial decomposition を用いて並列化された分子動力学法プログラ ムをPCクラスタ上に実装し、その並列性能を評価した。また、お よそ2 百万原子によるき裂問題の解析を PC クラス夕環境で行い、 妥当な結果を得ることができた。

\section{参考文献}

[1] Kohlhoff, S., Gumbsch, P. and Fischmeister, H., Phil. Mag., A, 64(1991), pp.851-878.

[2] Abraham, F., F., et al, J. Mech. Phys. Solids, 45(1997), pp. 1461-1471

[3] Johnson, R. A., Phys. Rev. A, 134(1964), pp.1329-1336

[4] Swope., W. C., et al, J. Chem. Phys., 76(1982), p.637

[5] 岡田、奥田、日本機械学会第 11 回計算力学講演会講演論文集, p.79 